\title{
Report on the ocurrence of Angiostrongylus costaricensis in southem Brazil, in a new intermediate host from the genus Sarasinula (Veronicellidae, Gastropoda)
}

\author{
Registro de Angiostronghus costaricensis no sul do Brasil, em novo hospedeiro \\ intermediario do gênero Sarasinula (Veronicellidae, Gastropoda)
}

\begin{abstract}
Antonio Carlo Laitano1, Júlia Pasquali Genro1, Ricardo Fontoura1, Susana Siqueira
Lima Branco', Rafael Lucyk Maurer ${ }^{1}$, Carlos Graeff-Teixeira ${ }^{1}$, José Maria Milanez ${ }^{3}$, Luís Antônio Chiaradia ${ }^{3}$ and José Willibaldo Thomé ${ }^{2}$
\end{abstract}

\begin{abstract}
Veronicellid slugs are the main intermediate hosts for Angiostrongylus costaricencis. In a rural locality in Nova Itaberaba (SC, southern Brazil) Sarasinula linguaeformis was identified as a crop pest. The parasitological examination revealed A. costaricencis infection in 43 out ot 50 slugs. The prevalence of $86 \%$ and the individual parasitic burdens are the highest sofar reported in Brazil and S. linguaeformis is the first species from the genus Sarasinula to be identified as intermediate host for A. costaricencis in southern Brazil. Key-words: Angiostrongylus. Veronicellidae. Sarasinula. Zoonosis.
\end{abstract}

Resumo Lesmas veronicelídeas são os principais hospedeiros intermediários de Angiostrongylus costaricencis. Em uma localidade rural de Nova Itaberaba (SC, no sul do Brasil) Sarasinula linguaeformis apresenta-se como peste agrícola. O exame parasitológico das lesmas demonstrou infecção pelo A. costaricencis em 43 de 50 animais. A prevalência de $86 \%$ e as cargas parasitárias são as mais altas registradas até o momento no Brasil e S. linguaeformis é a primeira espécie do gênero Sarasinula a ser identificado como hospedeiro intermediário do A. costaricencis no sul do país.

Palavras-chaves: Angiostrongylus. Veronicellidae. Sarasinula. Zoonosis.

Angiostrongylus costaricensis Morera and Céspedes, 1971 is a parasitic nematode from wild rodents, with a widespread geographic distribution, from southern United States ${ }^{6}$ to northern Argentina ${ }^{2}$ and southern Brazil ${ }^{3}$. Terrestrial molluscs are the main intermediate hosts, especially from the Veronicellidae family, such as Phyllocaulis variegatus (Semper, 1885) in southern Brazil ${ }^{5}$ and Sarasinula plebeia (Fisher, 1868) (syn.: Vaginulus plebeius) in Central America ${ }^{4}$.

Besides its importance as a biological vector for this nematode, veronicellid slugs may also be a crop pest ${ }^{1}$. Recently this problem was detected in the southwestern municipality of Nova Itaberaba, State of Santa Catarina (2900'00" S; 5310'00"W). The slugs were identified as Sarasinula sp, probably S. linguaeformis. A sample of 50 slugs was sent for parasitological examination. Eviscerated bodies of the slugs were individually minced and incubated for $1 \mathrm{hr}$, at $37^{\circ} \mathrm{C}$, in $0.03 \%$ (w/v) Pepsin (Sigma, P7125) and $0.7 \%(\mathrm{v} / \mathrm{v})$ aqueous solution. These preparations were left in Baermann funnels, and the sediment was examined after $6 \mathrm{~h}$.

Prevalence of $A$. costaricensis infection in this population was $86 \%: 43$ out of 50 slugs were found to be infected. A sample of 64 larvae was inoculated into Swiss mice (8 animals), by gastric entubation, leading to the recovery of adult $A$. costaricensis worms, from its intra-arterial location in the mesentery.

Among the individual parasitic burdens now reported, $7720 \mathrm{~L} 3$ is the highest number found in naturally infected animals in southern Brazil. Also the frequency distribution

\footnotetext{
1. Laboratórios de Biologia Parasitária e Parasitologia Molecular; 2. Laboratório de Malacologia, Faculdade de Biociências e Instituto de Pesquisas Biomédicas da Pontifícia Universidade Católica do Rio Grande do Sul (PUCRS),Porto Alegre RS, Brasil; 3. Centro de Pesquisas para Pequenas Propriedades, EPAGRI-SC, Chapecó, SC.

Apoio financeiro: CNPq, CAPES, FAPERGS, PUCRS.

Address to: Dr. Carlos Graeff-Teixeira. Av Ipiranga 6690. IPB 2 andar, sala 20, 90690-900 Porto Alegre, RS, Brasil

e-mail: graetei@pucrs.br

Recebido para publicação em 18/8/2000.
} 
(Table 1) of parasitic burdens shows that from most of the infected slugs (51\%) less then 10 L3 were recovered by the artificial digestion method. These data confirm previous findings with naturally infected molluscs from several other transmission foci ${ }^{5}$, shown for comparison in Table 2 against $P$. variegatus - so far considered the most important intermediate host. The number of slugs with parasitic burdens higher than 50 L3 was much higher $(21 \%)$ than that previously reported by the same authors (7\%).

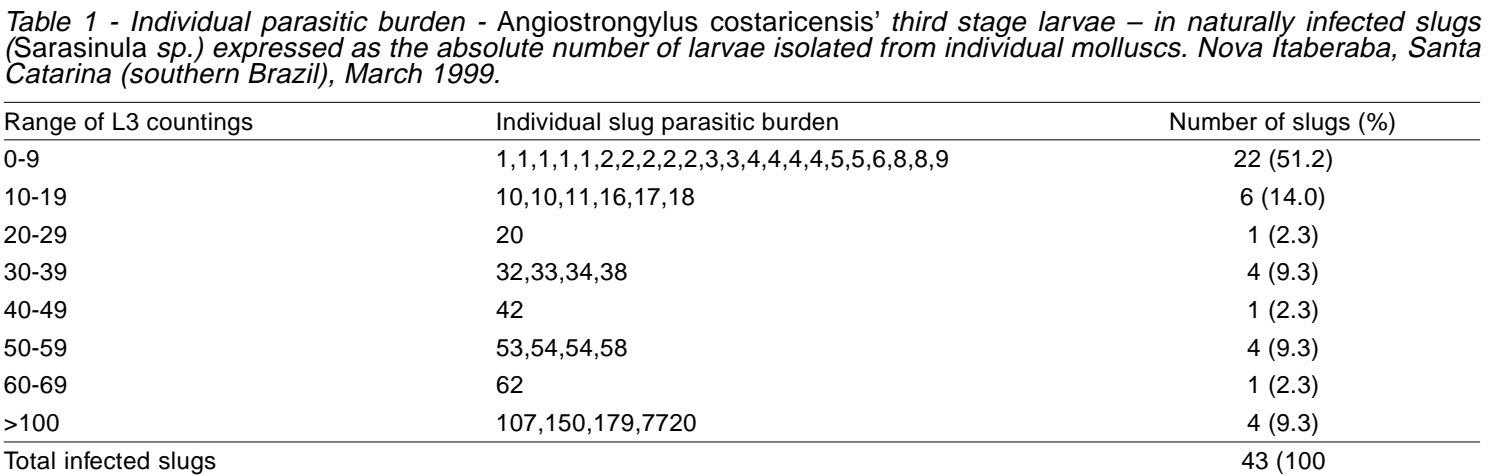

Table 2 - Parasitic burden in Phyllocaulis variegatus found infected in 11 transmission foci of abdominal angiostrongyliasis in Rio Grande do Sul (southern Brazil), expressed as the absolute number of larvae isolated from individual molluscs. January 1994 to April 1995. Modified from Rambo et al, Memórias do Instituto Oswaldo Cruz 92:9-14, 1997.

\begin{tabular}{llc}
\hline Range of L3 countings & Individual slug parasitic burden & Number of slugs (\%) \\
\hline $0-9$ & $1,1,1,1,1,1,1,1,1,1,1,1,2,2,3,3,4,4,6,8,9$ & $21(75 \%)$ \\
$10-19$ & $11,14,19$ & $3(11 \%)$ \\
$20-29$ & 20 & $1(3.5 \%)$ \\
$30-39$ & 38 & $1(3.5 \%)$ \\
$40-49$ & & 0 \\
$50-59$ & & 0 \\
$60-69$ & 69 & $1(3.5 \%)$ \\
$70-79$ & 75 & $1(3.5 \%)$ \\
$>100$ & & 0 \\
\hline Total infected slugs & & $28(100)$ \\
\hline
\end{tabular}

There is no documented human case of abdominal angiostrongyliasis in the municipality, but the entire southwestern region of Santa Catarina is endemic for this zoonotic parasitosis and probably it is underdiagnosed, since usually only the most severe disease is diagnosed.

These findings stress the importance of veronicellid slugs, specially the genus Sarasinula, as hosts for $A$. costaricensis and indicates that the species found naturally infected in Nova Itaberaba may be such an important host as $P$. variegatus. They also add evidence for the diversity of host species and the relative lack of specificity of this metastrongylid regarding its intermediate hosts.

\section{REFERENCES}

1. Andrews KL, Mira A. Relación entre densidad poblacional de la babosa Vaginulus plebeius y el daño en frijol comun, Phaseolus vulgaris. Turrialba, Tegucigalpa 33:165-168, 1983.

2. Demo OJ, Pessat OAN. Angiostrongilosis abdominal. Primer caso humano encontrado em Argentina. Prensa Médica Argentina 73:732-738, 1986.
3. Graeff-Teixeira C, Camillo-Coura L, Lenzi HL. Clinical and epidemiological studies on abdominal angiostrongyliasis in southern Brazil. Revista do Instituto de Medicina Tropical de São Paulo 33:375-80, 1991.

4. Morera P. Life history and redescription of Angiostrongylus costaricensis Morera and Céspedes, 1971. The American Journal of Tropical Medicine and Hygiene 22:613-21, 1973. 
5. Rambo PR, Agostini AA, Graeff-Teixeira C. Abdominal angiostrongylosis in Southern Brazil - prevalence and parasitic burden in mollusc intermediate hosts from eighteen endemic foci. Memórias do Instituto Oswaldo Cruz 92:9-14, 1997.
6. Ubelaker JE, Hall NM. First Report of Angiostrongylus costaricensis Morera and Céspedes, 1971 in the United States. Journal of Parasitology 65:307, 1979. 